Check for updates

Cite this: RSC Adv., 2019, 9, 22137

\title{
A titanium tetrachloride-based effective methodology for the synthesis of dipeptides $\uparrow$
}

\author{
Alessandra Comandè, Marianna Greco, Emilia Lucia Belsito, Angelo Liguori \\ and Antonella Leggio (D) *
}

A series of dipeptide systems have been easily achieved through a $\mathrm{TiCl}_{4}$-assisted condensation reaction. The reaction of $\mathrm{N}$-protected amino acids with amino acid methyl esters in pyridine and in the presence of $\mathrm{TiCl}_{4}$ furnished the corresponding dipeptides with high yields and diastereoselectivity. The reaction was successfully applied to amino acids protected on the $\alpha$-amino function with different protecting groups. The adopted experimental conditions allowed preserving both the protecting groups on the $\alpha$ amino function and on the side chain functionalities. Furthermore, the preservation of the stereochemical integrity at the amino acid chiral centres has been verified.

Received 29th May 2019

Accepted 9th July 2019

DOI: $10.1039 / \mathrm{c} 9 \mathrm{ra0} 4058 \mathrm{~g}$

rsc.li/rsc-advances

to prevent the glycosylation of proteins and in particular of hemoglobin, a process that characterizes the metabolic

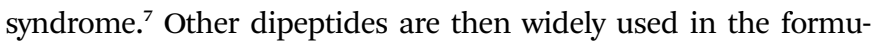
lation of cosmetic products for instance cysteine-containing dipeptides, ${ }^{8}$ L-Tyr-L-Arg ${ }^{9}$ and aspartyl dipeptides, the latter possess highly effective skin and hair caring properties..$^{10}$

Amide bond formation is an extremely important reaction in organic chemistry. ${ }^{11}$ Numerous synthetic strategies to synthesize organic molecules containing amide bonds and peptides have been reported. ${ }^{12}$

The development of solid-phase peptide synthesis (SPPS), also automated, has made easily available polypeptides of great interest for food, pharmaceutical and biomedical purposes. ${ }^{13}$

Solution phase peptide synthesis (commonly referred to as 'liquid phase') is the method of choice for preparing dipeptides and more generally small peptides. This strategy, although is not well suited for making longer peptides, is much more scalable, and allows to produce larger quantities of high-quality peptides, and at a lower cost than solid phase.

Peptide synthesis strategies in solution, but also in solid phase, require the protection of chemical functions not involved in the formation of the peptide bond. The formation of this bond is of particular importance for the purposes of stereochemistry preservation of the chiral centres of the amino acids that participate in the condensation reaction.

Therefore, the development of new methods of peptide bond formation in liquid phase is particularly attractive in order to obtain dipeptides or small peptides since this methodology can also be used with non-natural or unusual amino acids.

In this context, titanium tetrachloride could assume great importance as, due to its great affinity for the oxygen atom, it is used in organic synthesis for the transformation of various functional groups. ${ }^{14}$

Dipartimento di Farmacia e Scienze della Salute e della Nutrizione, Università della Calabria Edificio Polifunzionale, I-87036 Arcavacata di Rende, CS, Italy. E-mail: antonella.leggio@unical.it; Fax: +39 984 493265; Tel: +39 984493199

$\dagger$ Electronic supplementary information (ESI) available: Spectral data and copies of the ${ }^{1} \mathrm{H}$ NMR and ${ }^{13} \mathrm{C}-\mathrm{NMR}$ spectra of dipeptides 1-20 and MS (EI) spectra of dipeptides 1-6 and 18-20; GC/MS (EI) analyses of dipeptides 3-4, 18-19 and 20. See DOI: $10.1039 / \mathrm{c} 9 \mathrm{ra} 04058 \mathrm{~g}$ 
In this study, we explored the applicability of titanium tetrachloride for the formation of the peptide bond. Our results have shown the successful use of titanium tetrachloride as condensing agent for the synthesis of dipeptide systems. Furthermore, the preservation of stereochemical integrity at the amino acid chiral centres has been verified.

\section{Results and discussion}

The possibility of using titanium tetrachloride $\left(\mathrm{TiCl}_{4}\right)$ for the formation of the peptide bond was by no means obvious. In fact, $\mathrm{TiCl}_{4}$ could deprotect not only the amino functions of $\mathrm{N}$ protected amino acids as it occurs with other Lewis acids ${ }^{15}$ but also the amino acid side chain functional groups.

Accordingly, we thought to carry out the reaction in a pyridine-buffered medium. We proceeded preliminarily with the synthesis of the dipeptide Asp-Phe-OMe (Aspartame), via the Boc-based solution-phase approach.

In this perspective, L-phenylalanine methyl ester hydrochloride $(1 \mathrm{mmol})$ was preliminary treated with pyridine $(5 \mathrm{~mL})$, then $N$-Boc-L-aspartic acid- $\beta$ - $t$-butyl ester $(1 \mathrm{mmol})$ and $\mathrm{TiCl}_{4}(2$ $\mathrm{mmol}$ ) were added to the resulting solution (Scheme 1). The reaction was carried out in a screw-capped vial at $40{ }^{\circ} \mathrm{C}$ and was complete within about $5 \mathrm{~h}$. After removal of pyridine by coevaporation with toluene, the resulting crude product was suspended in chloroform and purified by elution through a silica gel column using chloroform as mobile phase. After evaporation of chloroform the dipeptide $N$-Boc-Asp-(OtBu)-Phe-OMe (1) was recovered in $84 \%$ yield and high purity as confirmed by ${ }^{1} \mathrm{H}$ and ${ }^{13} \mathrm{C}$ NMR analyses. Spectroscopic data analysis excluded side-chain and N-terminal amino function deprotection.

Afterwards Aspartame (Asp-Phe-OMe) (1a) was readily obtained in $95 \%$ yield by treating the $N$-Boc-protected dipeptide 1 with trifluoroacetic acid in dichloromethane $(1: 1 \mathrm{v} / \mathrm{v})$.

The developed procedure was applied successfully for the synthesis of various $N$-Boc-protected dipeptides (Scheme 2 and Table 1).

All the $N$-Boc-dipeptides 2-6 were characterized by GC/MS (EI), ${ }^{1} \mathrm{H}$ NMR and ${ }^{13} \mathrm{C}$ NMR analyses. $N$-Boc-Ala-Cys-(SBzl)OMe (5) and $N$-Boc-Ala-Lys-(Boc)-OMe (6) kept unchanged the masking groups on the amino acid side-chains.

The successful outcomes obtained with the synthesis of dipeptides 1-6 prompted us to extend the developed methodology to the preparation of dipeptide systems protected on the $\alpha$-amino function with the base-labile protecting group fluorenylmethoxycarbonyl (Fmoc) (Scheme 3). N-Fmoc-dipeptide systems (7-17) were prepared in high yields without observing

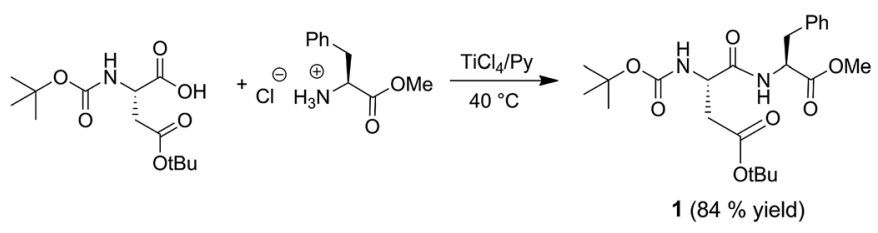

Scheme 1 Synthesis of dipeptide N-Boc-Asp-(OtBu)-Phe-OMe (1).

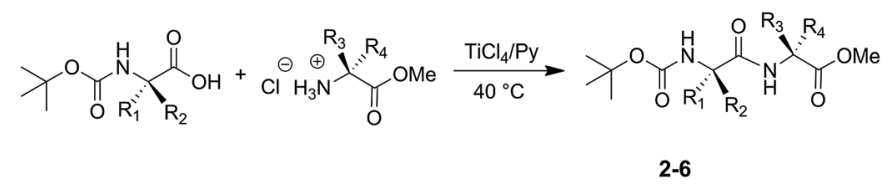

Scheme 2 Synthesis of $N$-Boc protected dipeptides 2-6.

the formation of reaction products deprotected on the $\alpha$-amino function (Table 2).

The stability of side-chain protecting groups was also investigated by carrying out the synthesis of dipeptides $N$ Fmoc-Asp-(OtBu)-Phe-OMe (7), $N$-Fmoc-Ser-(OtBu)-Ala-OMe (13), $N$-Fmoc-Ala-Cys-(SBzl)-OMe (14) and $N$-Fmoc-Ala-Lys(Boc)-OMe (15). In these cases, the reaction occurred without removal of the side-chain protecting groups and afforded the corresponding dipeptides in high yields (Scheme 3 and Table 2). In particular, the $t$-butyl group on the serine side-chain, the benzyl group on the cysteine side-chain and the Boc group on the lysine side-chain were preserved during the condensation reaction. Therefore using pyridine as reaction solvent has proved useful not only to convert the ammonium group of amino acid methyl ester hydrochloride into the free amino function able to react as nucleophile in the condensation reaction, but also to preserve the protecting groups on the masked functionalities.

The coupling reaction mediated by $\mathrm{TiCl}_{4}$ gave excellent results also when it was employed to get dipeptides protected on the amino terminal function with the benzyloxycarbonyl $(\mathrm{Cbz})$ protecting group in fact, $N$-Cbz-L-Ala-L-Ala-OMe (18), and $N$-Cbz-D-Ala-L-Ala-OMe (19) were obtained in good yields (Scheme 4).

For completeness, we applied the developed procedure to the synthesis of a dipeptide system protected on the amine function with the 4-nitrobenzenesulfonyl (nosyl) group. ${ }^{16}$

Nosyl group (Ns) is an interesting protecting group as it simultaneously protects and activates the $\mathrm{NH}_{2}$ moiety of amines, ${ }^{17}$ in fact, it is widely used for the site-selective $N$-alkylation of amino acids and peptides both in solution and solid phase. $^{18}$

The condensation reaction mediated by $\mathrm{TiCl}_{4}$ proceeded in a different way when the amino function of the $\mathrm{N}$-terminal amino acid was protected with the nosyl group.

The reaction between $N$-Ns-L-phenylalanine and alanine methyl ester hydrochloride for obtaining the dipeptide $N$-Ns-LPhe-L-Ala-OMe (20) was particularly slow.

Table 1 Results of the synthesis of $N$-Boc-dipeptides 2-6

\begin{tabular}{llllll}
\hline Dipeptide & $\mathrm{R}_{1}$ & $\mathrm{R}_{2}$ & $\mathrm{R}_{3}$ & $\mathrm{R}_{4}$ & Yield $^{a}(\%)$ \\
\hline $\mathbf{2}$ & $\mathrm{CH}_{2} \mathrm{C}_{6} \mathrm{H}_{5}$ & $\mathrm{H}$ & $\mathrm{CH}_{3}$ & $\mathrm{H}$ & 75 \\
$\mathbf{3}$ & $\mathrm{CH}_{3}$ & $\mathrm{H}$ & $\mathrm{CH}_{3}$ & $\mathrm{H}$ & 71 \\
$\mathbf{4}$ & $\mathrm{H}$ & $\mathrm{CH}_{3}$ & $\mathrm{CH}_{3}$ & $\mathrm{H}$ & 80 \\
$\mathbf{5}$ & $\mathrm{CH}_{3}$ & $\mathrm{H}$ & $\mathrm{CH}_{2} \mathrm{~S}-(\mathrm{Bzl})$ & $\mathrm{H}$ & 80 \\
$\mathbf{6}$ & $\mathrm{CH}_{3}$ & $\mathrm{H}$ & $\left(\mathrm{CH}_{2}\right)_{4} \mathrm{NH}-(\mathrm{Boc})$ & $\mathrm{H}$ & 80
\end{tabular}

${ }^{a}$ Isolated yield. 


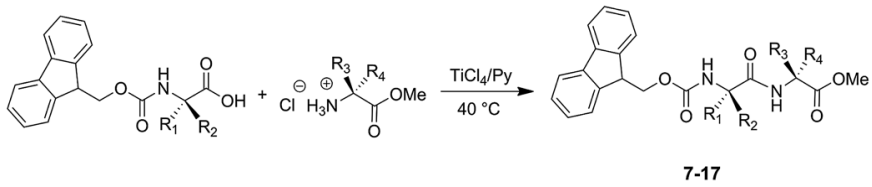

Scheme 3 Synthesis of N-Fmoc protected dipeptides 7-17

After 7 hours, the TLC analysis (chloroform-methanol, $90: 10, v / v)$ of reaction mixture still showed the presence of $N$ Ns-L-phenylalanine, then the reaction was stopped. After applying to the reaction mixture the previously described workup, the reaction product, recovered in $48 \%$ yield, was analyzed by GC/MS (EI). The resulting chromatogram gave two peaks at $\mathrm{tr}=46.42 \mathrm{~min}$ and $\mathrm{tr}=46.87 \mathrm{~min}$ in about $3: 1$ ratio respectively with identical mass spectra both characterized by the presence of the molecular ion $\mathrm{m} / \mathrm{z} 376$ consistent with that of dipeptide $\mathrm{N}$-Ns-Phe-L-Ala-OMe (20) and its corresponding diastereoisomer.

The ${ }^{1} \mathrm{H}$ NMR spectrum of the product also provided evidence of the presence of a mixture of two diastereoisomers in fact it showed, only for a few types of protons, the presence of two close signals of different intensity corresponding to the two stereoisomers.

Therefore, when $\mathrm{N}$-nosyl amino acids are used as N-terminal residues the reaction is incomplete, probably because of the presence of the sulfonamide function, and the stereochemical integrity of the chiral centers is not completely retained.

This result prompted us to verify, also in the cases of Boc-, Cbz- and Fmoc-protected dipeptides, the configuration preservation of the amino acids chiral centers.

To this aim, we designed and carried out the synthesis of couples of diastereoisomeric dipeptides protected on the amino function with the above-cited urethane protecting groups.

Under the typical reaction conditions by using $\mathrm{TiCl}_{4} / \mathrm{pyridine}$ reagent system, the dipeptide $N$-Boc-L-Ala-L-Ala-OMe (3) and its epimer $N$-Boc-D-Ala-L-Ala-OMe (4) were synthesized. Samples of the crude dipeptides 3 and 4 were analyzed by ${ }^{1} \mathrm{H}$ NMR and ${ }^{13} \mathrm{C}$ NMR and the resulting spectra were compared with that obtained analyzing a mixture, of the same two epimers.

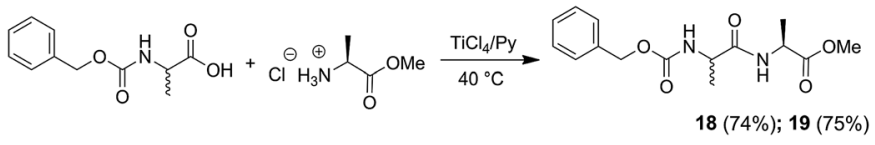

Scheme 4 Synthesis of $N$-Cbz protected dipeptides 18-19.

${ }^{1} \mathrm{H}$ NMR spectra of both single products 3 and $\mathbf{4}$ showed the presence of signals attributable to only one diastereomer and the absence of epimerized products at least within the sensibility limits of the NMR technique. The chemical shifts of the signals generated by the $\mathrm{NH}$ amide protons were different in the two diastereoisomers and readily resolved in the ${ }^{1} \mathrm{H}$ NMR spectrum of the mixture of 3 and $\mathbf{4}$, prepared for this purpose, with a ratio $4: 6$ respectively (Fig. 1).

The GC/MS analysis of the two epimers $N$-Boc-L-Ala-L-AlaOMe dipeptides (3) and $N$-Boc-D-Ala-L-Ala-OMe (4) instead, indicated the presence in both chromatogram of a very small

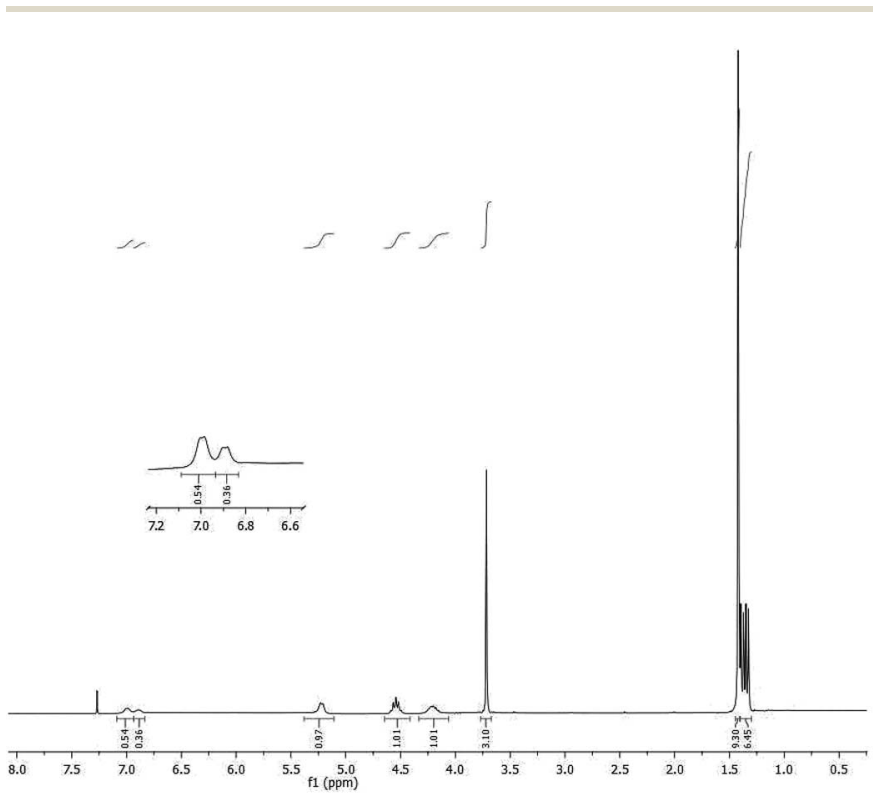

Fig. $1{ }^{1}$ H NMR spectrum of a mixture of 3 and 4 (approx. $4: 6$ ).

Table 2 Results of the synthesis of $N$-Fmoc-dipeptides 7-17

\begin{tabular}{|c|c|c|c|c|c|}
\hline Dipeptide & $\mathrm{R}_{1}$ & $\mathrm{R}_{2}$ & $\mathrm{R}_{3}$ & $\mathrm{R}_{4}$ & Yield $^{a}(\%)$ \\
\hline 7 & $\left(\mathrm{CH}_{2}\right) \mathrm{COO}-(t \mathrm{Bu})$ & $\mathrm{H}$ & $\mathrm{CH}_{2} \mathrm{Ph}$ & $\mathrm{H}$ & 84 \\
\hline 8 & $\mathrm{CH}_{3}$ & $\mathrm{H}$ & $\mathrm{CH}_{3}$ & $\mathrm{H}$ & 71 \\
\hline 10 & $\mathrm{H}$ & $\mathrm{CH}_{2} \mathrm{CH}\left(\mathrm{CH}_{3}\right)_{2}$ & $\mathrm{CH}_{3}$ & $\mathrm{H}$ & 80 \\
\hline 11 & $\mathrm{H}$ & $\mathrm{H}$ & $\mathrm{CH}_{3}$ & $\mathrm{H}$ & 80 \\
\hline 12 & $\mathrm{CH}_{2} \mathrm{CH}\left(\mathrm{CH}_{3}\right)_{2}$ & $\mathrm{H}$ & $\mathrm{CH}\left(\mathrm{CH}_{3}\right) \mathrm{CH}_{2} \mathrm{CH}_{3}$ & $\mathrm{H}$ & 87 \\
\hline 15 & $\mathrm{CH}_{3}$ & $\mathrm{H}$ & $\left(\mathrm{CH}_{2}\right)_{4} \mathrm{NH}-(\mathrm{Boc})$ & $\mathrm{H}$ & 60 \\
\hline 16 & $\mathrm{CH}_{2} \mathrm{~S}-(\mathrm{Bzl})$ & $\mathrm{H}$ & $\mathrm{CH}_{3}$ & $\mathrm{H}$ & 78 \\
\hline 17 & $\mathrm{H}$ & $\mathrm{CH}_{2} \mathrm{~S}-(\mathrm{Bzl})$ & $\mathrm{CH}_{3}$ & $\mathrm{H}$ & 74 \\
\hline
\end{tabular}

${ }^{a}$ Isolated yield. 
amount of the other epimer, the calculated diastereomeric excess was for both epimers satisfactory ( $\geq 95 \%)$.

A diastereomeric excess $\geq 96 \%$ was measured by analyzing by GC/MS the single dipeptides $N$-Cbz-L-Ala-L-Ala-OMe (18) and its epimer $N$-Cbz-D-Ala-L-Ala-OMe (19).

The ${ }^{1} \mathrm{H}$ NMR spectra of the single products 18 and 19 did not show residual signals attributable to the other diastereomer while, in the ${ }^{1} \mathrm{H}$ NMR analysis of a mixture of 18 and 19, approximately $4.2: 5.8$ respectively, the signals corresponding to the amide proton (6.89 ppm, $6.83 \mathrm{ppm})$ and to the methyl ester protons (3.72 ppm, $3.73 \mathrm{ppm}$ ) of the two epimers resulted separated.

Finally, also the dipeptides $N$-Fmoc-L-Leu-L-Ala-OMe (9) and $N$-Fmoc-D-Leu-L-Ala-OMe (10), obtained through the developed methodology, showed no detectable loss of stereo integrity. In fact ${ }^{1} \mathrm{H}$ NMR spectra of both single products $\mathbf{9}$ and 10 indicated the presence of signals corresponding to only one diastereomer while in the ${ }^{1} \mathrm{H}$ NMR spectrum of a mixture of both epimers 9 and $\mathbf{1 0}$ the chemical shifts of amide and urethanic protons were resolved.

Additional experiments have been performed in order to test the epimerization process when sensitive $\mathrm{Cys}(\mathrm{Bzl}) \mathrm{OH}$ is used as $\mathrm{N}$-terminal residue. To this aim we synthesized a couple of diastereomeric dipeptide systems $N$-Fmoc-L-Cys(Bzl)-L-Ala-OMe (16) and $N$-Fmoc-D-Cys(Bzl)-L-Ala-OMe (17) (Scheme 3 and Table 2). In the crude ${ }^{1} \mathrm{H}$ NMR spectra of both systems (16 and 17) the presence of about $10 \%$ of the other diastereoisomer has been detected indicating in this case a higher epimerization level. In particular, we observed in both spectra two different signals corresponding to the $\mathrm{NH}$ amide proton in a ratio of about $0.9: 0.1$.

The formation of peptide bond under the adopted reaction conditions could occur through the mechanism depicted in Scheme 5 . We hypothesized that $\mathrm{TiCl}_{4}$ interacts with the $\mathrm{N}$ protected amino acid pyridinium salt by forming the
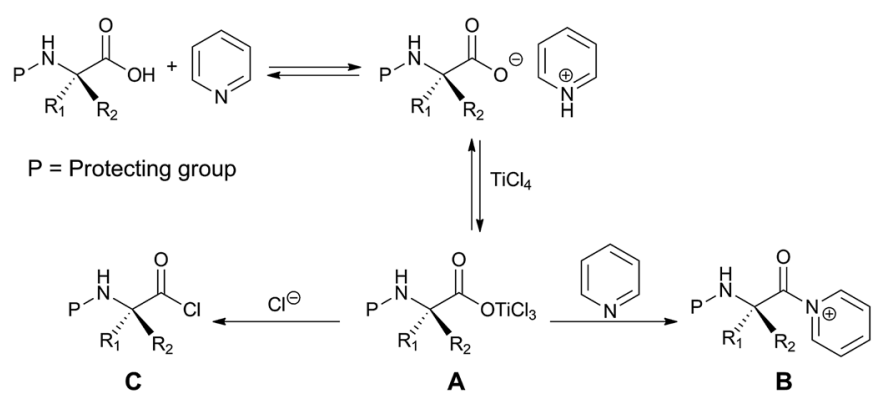

C

B

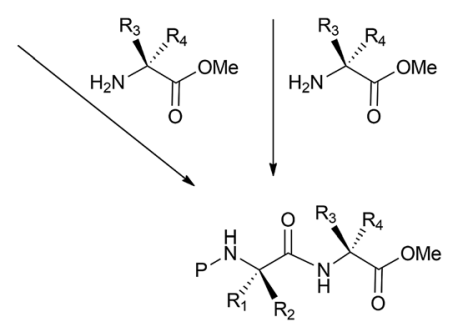

Scheme 5 Proposed mechanism for the $\mathrm{TiCl}_{4}$-mediated synthesis of dipeptides. intermediate A. This could react with the amino acid methyl ester directly or after conversion into the corresponding chloride (C) or acyl pyridinium ion (B) to form the dipeptide system.

\section{Conclusions}

Here we developed a synthetic process mediated by $\mathrm{TiCl}_{4}$ that yields dipeptide systems having high stereochemical and chemical purity. $\mathrm{TiCl}_{4} /$ pyridine reagent system represents a valuable tool for synthesizing peptides. Dipeptide systems were synthesized easily and in high yields through a $\mathrm{TiCl}_{4}$ assisted condensation reaction between $\mathrm{N}$-protected amino acids and amino acid methyl esters in pyridine.

The reaction was applied successfully to amino acids protected on the $\alpha$-amino function with different protecting groups. The adopted experimental conditions allowed preserving not only the $\alpha$-amino protecting groups but also the acid-labile side chain protecting groups.

The recovery of the dipeptide products has been achieved by simple filtration through a silica gel column, which greatly simplifies the reaction work-up and avoids the formation of emulsions and product losses.

The maintenance of amino acids stereochemical integrity is almost complete for dipeptides protected on the amino function with urethane protecting groups (Fmoc, Z, Boc). A nonnegligible loss of stereochemical integrity was instead observed in $N$-nosyl-protected dipeptides.

\section{Experimental}

\section{General experimental details}

Reagents were commercially available with analytical grade and used as purchased without further purification. Solvents were purified according to well-known laboratory methods and freshly distilled prior to use. Reaction were carried out in a tightly sealed screw-capped vial. Reactions were magnetically stirred and monitored by thin layer chromatography using Merck-Kieselgel 60 F254 plates. Spots on the TLC plates were visualized with a UV lamp (254 $\mathrm{nm}$ ) and by spraying with $0.2 \%$ ninhydrin in ethanol and charring after elution. ${ }^{1} \mathrm{H}$ and ${ }^{13} \mathrm{C}$ NMR spectra were recorded on a Bruker Avance 300 instrument at $300 \mathrm{MHz}$ and $75 \mathrm{MHz}$, respectively. Spectroscopic analysis was performed at $293 \mathrm{~K}$ on diluted solutions of each compound by using $\mathrm{CDCl}_{3}$ or DMSO- $\mathrm{d}_{6}$ as solvents. Chemical shifts $(\delta)$ are reported in ppm. Coupling constants $(J)$ are reported in Hertz (Hz). GC-MS analyses were performed with a DB-35MS $(20 \mathrm{~m} \times$ $0.18 \mathrm{~mm}, 35 \%$ phenyl $65 \%$ dimethylpolysiloxane) capillary column. The mass detector was operated in the electron impact ionization mode (EI/MS) with an electron energy of $70 \mathrm{eV}$. The injection port was heated to $250{ }^{\circ} \mathrm{C}$. The oven temperature program was initially set at $70{ }^{\circ} \mathrm{C}$ with a hold of $2 \mathrm{~min}$ and ramped to $280{ }^{\circ} \mathrm{C}$ at $20{ }^{\circ} \mathrm{C} \mathrm{min}{ }^{-1}$ with a hold of $10 \mathrm{~min}$. In order to obtain a good separation of diastereisomers the oven temperature program was initially set at $40{ }^{\circ} \mathrm{C}$ with a hold of $2 \mathrm{~min}$ and ramped to $280{ }^{\circ} \mathrm{C}$ at $5^{\circ} \mathrm{C} \mathrm{min}^{-1}$ with a hold of $10 \mathrm{~min}$. 


\section{General procedure for the synthesis of dipeptides 1-18}

$\alpha$-Amino acid methyl ester hydrochloride $(1 \mathrm{mmol})$ is first solubilized in $5 \mathrm{~mL}$ of anhydrous pyridine by magnetic stirring. After about 5 minutes the $\mathrm{N}$-protected- $\alpha$-amino acid $(1 \mathrm{mmol})$ and $\mathrm{TiCl}_{4}(2 \mathrm{mmol})$ are added. The tightly sealed screw-capped vial containing the reaction mixture is left under magnetic stirring at $40{ }^{\circ} \mathrm{C}$, maintaining the $\mathrm{pH}$ at values as close as possible to neutrality by adding further amounts of pyridine. The reaction, monitored by TLC analysis (chloroform-methanol, $90: 10, \mathrm{v} / \mathrm{v}$ ), is completed after about 5 hours. After removal of pyridine by co-evaporation with toluene, the resulting crude product is suspended in chloroform and purified by elution through a silica gel column also containing a layer of $\mathrm{NaHCO}_{3}$ and one of $\mathrm{NaHSO}_{4}$ separated by a silica gel one and using chloroform as mobile phase. The evaporation of chloroform under reduced pressure affords the corresponding $\mathrm{N}$ protected dipeptide 1-18 with yields ranging from 60 to $87 \%$.

$\boldsymbol{N}$-Boc-L-Phe-L-Ala-OMe (2). White solid (0.140 g), 75\% yield; $\mathrm{mp}=95-97{ }^{\circ} \mathrm{C} ; \mathrm{Rf}=0.85 ;{ }^{1} \mathrm{H} \mathrm{NMR}\left(300 \mathrm{MHz}, \mathrm{CDCl}_{3}\right) \delta: 7.34-$ $7.13(\mathrm{~m}, 5 \mathrm{H}, \mathrm{ArH}), 6.66\left(\mathrm{~s}_{\text {broad }}, 1 \mathrm{H}, \mathrm{CONH}\right), 5.14(\mathrm{~d}, J=7.9 \mathrm{~Hz}$, $1 \mathrm{H}, \mathrm{OCONH}), 4.51\left(\mathrm{~m}, 1 \mathrm{H}, \mathrm{CHCOOCH}_{3}\right), 4.40(\mathrm{~m}, 1 \mathrm{H}$,

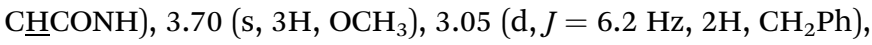
$1.39\left(\mathrm{~s}, 9 \mathrm{H},\left(\mathrm{CH}_{3}\right)_{3} \mathrm{C}\right), 1.33\left(\mathrm{~d}, J=7.2 \mathrm{~Hz}, 3 \mathrm{H}, \mathrm{CH}_{3} \mathrm{CH}\right) ;{ }^{13} \mathrm{C} \mathrm{NMR}$ $\left(75 \mathrm{MHz}, \mathrm{CDCl}_{3}\right) \delta: 172.82,170.82,155.38,136.58,129.35$, 128.56, 126.88, 80.14, 55.53, 52.33, 48.08, 38.36, 28.22, 18.25; GC/MS (EI, $70 \mathrm{eV}$ ) m/z (\% rel.): 294 (11), 277 (7), 263 (4), 248 (1) 233 (18), 220 (10), 191 (3.7), 178 (15), 164 (41.5), 159 (27), 146 (9), 120 (100), 91 (52), 57 (94). Found: C, 61.49; H, 7.45; N, 7.96. $\mathrm{C}_{18} \mathrm{H}_{26} \mathrm{~N}_{2} \mathrm{O}_{5}$ requires $\mathrm{C}, 61.70 ; \mathrm{H}, 7.48 ; \mathrm{N}, 7.99 \%$.

\section{Conflicts of interest}

There are no conflicts to declare.

\section{Acknowledgements}

This work was supported by grants from MIUR (Ministero Italiano dell'Università e della Ricerca, ex-60\% funds).

\section{Notes and references}

1 (a) M. S. Iyer, K. M. Gigstad, N. D. Namdev and M. Lipton, J. Am. Chem. Soc., 1996, 118, 4910-4911; (b) J. Oku, N. Ito and S. Inoue, Makromol. Chem., 1979, 180, 1089-1091.

2 (a) M. Yagasaki and S. Hashimoto, Appl. Microbiol. Biotechnol., 2008, 81, 13-22; (b) J. Arima, Y. Uesugi, M. Uraji, M. Iwabuchi and T. Hatanaka, Appl. Environ. Microbiol., 2006, 72, 4225-4231.

3 (a) V. K. Khavinson and V. N. Anisimov, Dokl. Akad. Nauk, 2000, 372, 421-423; (b) M. Nath, S. Pokharia, G. Eng, X. Q. Song and A. Kumar, Spectrochim. Acta, Part A, 2006, 63, 66-75.

4 A. Guiotto, A. Calderan, P. Ruzza and G. Borin, Curr. Med. Chem., 2005, 12, 2293-2315.

5 D. D. Kitts and K. Weiler, Curr. Pharm. Des., 2003, 9, 13091323.
6 R. C. Harris, J. R. Hoffmanb, A. Allsoppc and N. B. H. Routledge, Nutr. Res., 2012, 32, 272-277.

7 B. C. Song, N.-S. Joo, G. Aldini and K.-J. Yeum, Nutr. Res. Pract., 2014, 8, 3-10.

8 T.-S. Tseng, K.-C. Tsai, W.-C. Chen, Y.-T. Wang, Y.-C. Lee, C.-K. Lu, M.-J. Don, C.-Y. Chang, C.-H. Lee, H.-H. Lin, H.-J. Hsu and N.-W. Hsiao, J. Agric. Food Chem., 2015, 63, 6181-6188.

9 K. Lintner and O. Peschard, Int. J. Cosmet. Sci., 2000, 22, 207218.

10 A. Sallam, M. Krehenbrink and D. Kalkandzhiev, WO 2017/ 162879 A1, 2017.

11 (a) F. Albericio, Curr. Opin. Chem. Biol., 2004, 8, 211-221; (b) T. Kimmerlin and D. Seebach, J. Pept. Res., 2005, 65, 229260.

12 (a) V. R. Pattabiraman and J. W. Bode, Nature, 2011, 480, 471-479; (b) A. El-Faham and F. Albericio, Chem. Rev., 2011, 111, 6557-6602; (c) R. De Marco, M. Spinella, A. De Lorenzo, A. Leggio and A. Liguori, Org. Biomol. Chem., 2013, 11, 3786-3796; (d) A. Leggio, E. L. Belsito, G. De Luca, M. L. Di Gioia, V. Leotta, E. Romio, C. Siciliano and A. Liguori, $R S C A d v ., 2016,6,34468-34475$; (e) A. Leggio, A. Comandè, E. L. Belsito, M. Greco, L. Lo Feudo and A. Liguori, Org. Biomol. Chem., 2018, 16, 5677-5683.

13 (a) R. B. Merrifield, J. Am. Chem. Soc., 1963, 85, 2149-2154; (b) M. L. Di Gioia, A. Leggio, A. Liguori and F. Perri, J. Org. Chem., 2007, 72, 3723-3728; (c) D. M. M. Jaradat, Amino Acids, 2018, 50, 39-68.

14 (a) M. T. Reetz, Organotitanium Reagents in Organic Synthesis, Springer-Verlag, Berlin, 1986; (b) M. L. Di Gioia, A. Leggio, A. Le Pera, A. Liguori, A. F. Pitrelli and C. Siciliano, Protein Pept. Lett., 2005, 12, 357-362; (c) A. Leggio, E. L. Belsito, M. L. Di Gioia, V. Leotta, E. Romio, C. Siciliano and A. Liguori, Tetrahedron Lett., 2015, 56, 2062-2066; (d) M. L. Di Gioia, A. Leggio, I. F. Guarino, V. Leotta, E. Romio and A. Liguori, Tetrahedron Lett., 2015, 56, 5341-5344; (e) A. Leggio, E. L. Belsito, S. Gallo and A. Liguori, Tetrahedron Lett., 2017, 58, 1512-1514; (f) A. Leggio, J. Bagalà, E. L. Belsito, A. Comandè, M. Greco and A. Liguori, Chem. Cent. J., 2017, 11(87), 1-12.

15 (a) A. Leggio, A. Liguori, A. Napoli, C. Siciliano and G. Sindona, Eur. J. Org. Chem., 2000, 5732575; (b) M. L. Di Gioia, A. Leggio, A. Le Pera, A. Liguori, F. Perri and C. Siciliano, Eur. J. Org. Chem., 2004, 4437-4441; (c) M. L. Di Gioia, A. Leggio, A. Le Pera, C. Siciliano, G. Sindona and A. Liguori, J. Pept. Res., 2004, 63, 383-387.

16 (a) A. Leggio, M. L. Di Gioia, F. Perri and A. Liguori, Tetrahedron, 2007, 63, 8164-8173; (b) R. De Marco, M. L. Di Gioia, A. Leggio, A. Liguori and M. C. Viscomi, Eur. J. Org. Chem., 2009, 3795-3800.

17 (a) T. Fukuyama, C.-K. Jow and M. Cheung, Tetrahedron Lett., 1995, 36, 6373-6374; (b) A. Le Pera, A. Leggio and A. Liguori, Tetrahedron, 2006, 62, 6100-6106.

18 (a) S. C. Miller and T. S. Scanlan, J. Am. Chem. Soc., 1997, 119, 2301-2302; (b) M. L. Di Gioia, A. Leggio, A. Liguori, F. Perri, C. Siciliano and M. C. Viscomi, Amino Acids, 2010, 38, 133143; (c) E. Biron and H. Kessler, J. Org. Chem., 2005, 70, 
5183-5189; (d) C. Aroulanda, G. Celebre, G. De Luca and M. Longeri, J. Phys. Chem. B, 2006, 110, 10485-10496; (e) E. L. Belsito, M. L. Di Gioia, A. Greco, A. Leggio, A. Liguori, F. Perri, C. Siciliano and M. C. Viscomi, J. Org. Chem., 2007, 72, 4798-4802; $(f)$ A. Leggio, E. L. Belsito, R. De
Marco, A. Liguori, F. Perri and M. C. Viscomi, J. Org. Chem., 2010, 75, 1386-1392; $(g)$ R. De Marco, A. Leggio, A. Liguori, T. Marino, F. Perri and N. Russo, J. Org. Chem., 2010, 75, 3381-3386; $(h)$ M. L. Di Gioia, A. Leggio and A. Liguori, J. Org. Chem., 2005, 70, 3892-3897. 